\title{
SOCIAL JUSTICE, SUSTAINABLE DEVELOPMENT AND QUALITY OF LIFE
}

Godfrey Netswera'

Jaya Josie ${ }^{2}$

Philani Mthembu ${ }^{3}$

Elias Phaahla ${ }^{4}$

Idah Makukule ${ }^{5}$

BRICS countries have emerged globally and achieved a greater role in promoting economic self-growth over the past years, but economic growth without addressing issues regarding social development can deep the existing social inequality within BRICS' societies. This paper discuss how BRICS countries fare in comparative terms on their social indicators: i) social development; ii) education; iii) health; and iv) cultural development, since these indicators have all been identified as integral to BRICS cooperation in the social sphere.

Keywords: BRICS; social development; education; health; cultural development.

\section{JUSTIÇA SOCIAL, DESENVOLVIMENTO SUSTENTÁVEL E QUALIDADE DE VIDA}

Nos últimos anos, os países do BRICS emergiram em escala global e desempenharam um papel ainda mais importante neste processo de crescimento econômico interno, mas um crescimento econômico sem abordar questões relativas ao desenvolvimento social pode aprofundar a desigualdade social existente nas sociedades do BRICS. Este artigo discute a forma como os países do BRICS se comportam em termos comparativos em relação aos seus indicadores sociais: i) desenvolvimento social; ii) educação; iii) saúde; e iv) desenvolvimento cultural, uma vez que todos estes indicadores foram identificados como parte integrante da cooperação dos BRICS na esfera social.

Palavras-chave: BRICS; desenvolvimento social; educação; saúde; desenvolvimento cultural.

\section{JUSTICIA SOCIAL, DESARROLLO SUSTENTABLE Y CALIDAD DE VIDA}

En los últimos años, los países del BRICS emergieron en escala global y desempeñaron un papel importante en el proceso de crescimento econômico. Sin embargo, crescimiento económico sin desarrollo social puede llevar a la profundización de la desigualdad social existente en las sociedades del BRICS. Este artículo discute la forma como los países del BRICS se comportam, em términos comparativos, con relación a sus indicadores sociales: i) desarrollo social; ii) educación; iii) salud; y iv) desarrollo cultural. Todos estos indicadores fueron identificados como parte integrante de la cooperación entre los países del BRICS en la esfera social.

Palabras clave: BRICS; desarrollo social; educación; salud; desarrollo cultural.

JEL: F50.

Data de envio do artigo: 10/3/2020; Data de aceite: 24/3/2020.

1. Prof. Godfrey Netswera, Durban University of Technology, South Africa.

2. Dr. Jaya Josie, Human Sciences Research Council, South Africa.

3. Dr. Philani Mthembu, Institute for Global Dialogue, South Africa.

4. Dr. Elias Phaahla, University of Cape Town, South Africa.

5. Dr. Idah Makukule, National Institute for Humanities and Social Sciences, South Africa. 


\section{INTRODUCTION}

Unlike the era of the Millennium Development Goals (MDGs), where developed countries were expected to be the key players in assisting developing countries to achieve their goals, the post-2015 international development landscape has been observing a greater role of Southern powers in that topic, such as the BRICS group of countries. While BRICS countries have played important roles as engines of self-growth, it is important to keep in mind that growth without social justice, sustainable forms of development, and quality of life for citizens only leads to more social problems within society.

It is thus important that BRICS countries are not only seen as a growth alliance but that they are playing an integral role as sources of sustainable development and quality of life for their citizens. And since the subsequent adoption of the Sustainable Development Goals (SDGs), the BRICS countries have played a greater role regionally and globally in promoting more policy space for developing countries to create programmes that help eradicate poverty and build prosperity.

Considering that BRICS countries should be able to monitor their progress on various human development indicators, this paper aims to discuss a desirable design of a template to be presented through the various annual reports that will be compiled at subsequent BRICS Think Tank Council (BTTC) meetings. This is relevant for streamlining it into an annual work plan that monitors BRICS countries on various social indicators and for understanding how BRICS countries can be compared on various social indicators.

\section{BRICS EFFORTS TO PROMOTE COOPERATION ON SOCIAL DEVELOPMENT}

While BRICS countries continue to face their own socio-economic challenges, they have been making important progress at addressing the living standards of their populations. They have also been playing important roles as sources of development cooperation and development finance across the developing world. This has meant that developing countries are no longer requesting for advice and cooperation at addressing socio-economic matters only to the Development Assistance Committee (DAC) of the Organisation for Economic Cooperation and Development (OECD).

BRICS countries are also at various stages of operationalising and institutionalising their international development agencies: South Africa's propose to create the South African Development Partnership Agency (SADPA) has yet to be operationalised; various reforms have led India to forming the Development Partnership Administration (DPA); the recent establishment of China's International Development Cooperation Agency (CIDCA) outlines a 
greater role for the country as a source of development cooperation; and the role of Brazil's Cooperation Agency (ABC) remains important.

The overall score of the Human Development Index (HDI) is a composite score measuring national progress in health, education, and income. The following table shows the overall rankings of BRICS countries amongst 189 countries with available data.

\section{TABLE1}

United Nations Development Programme (UNDP) Human Development Index (HDI) amongst BRICS countries (2018)

\begin{tabular}{llc}
\hline & HDI & HDI global ranking \\
\hline Brazil & 0.759 & 79 \\
Russian Federation & 0.816 & 49 \\
India & 0.64 & 130 \\
China & 0.752 & 86 \\
South Africa & 0.699 & 113 \\
\hline
\end{tabular}

Source: UNDP (2018).

The results demonstrate that while some of the economies of BRICS countries rank amongst the top ten globally in terms of GDP, their populations have not necessarily enjoyed comparable living standards with their counterparts in the developed world. It thus highlights the importance of various human development indicators across BRICS countries to showcase areas where progress is being made and areas that require additional focus in improving the lives of citizens in BRICS countries and the developing world.

The 2018 BRICS Summit Declaration in Johannesburg firmly located health, education and broader social development as imperative for capacity building. Skills development to capacitate its citizens is among the key themes repeated in the declaration including poverty alleviation. The BRICS partnership can be compared among other variables on its consistency in positions and posture with corresponding action, such as its constant emphasis on people centeredness as declared by summits since its inception.

What seems to be different, coming out of the Johannesburg summit, is an elevation of socio-economic development, in its individual components, fused into the top tier elements of its work, such as multilateralism, peace, security and others.

While recognising the centrality of people in its endeavours, the BRICS group has sought to strengthen this further through the support for the growing linkages amongst peoples and from BRICS countries. As an example of this recognition, the development of a treaty on the co-production of works (arts, culture and heritage) 
has now become an effort under realisation. Despite BRICS grouping being still young, it must seek to improve cooperation and coordination of efforts.

The BRICS bloc continues to demonstrate ambition and tenacity. To this end, among the several key points of the Johannesburg declaration, the following statement re-emphasises the need for the common development of the world's people.

We strongly acknowledge that skills development is critical to addressing the emerging mismatch between the new skills demanded by an increasingly technology-and knowledge-driven global economy and the older skill set of many workers. The pace, scale and scope of present-day economic change make it that more challenging. In this regard, we support measures including policy recommendations proposed in the G20 Initiative to Promote Quality Apprenticeship and the BRICS Action Plan for Poverty Alleviation and Reduction through Skills, to further facilitate vocational training, lifelong learning and training that is relevant to the fast-changing demands of growing economies and world of work (Brasil, 2018).

The following section provides an overview of the current position of the BRICS nations regarding the important indicators that promote social justice, sustainable development and quality of life. The rationale for the emergence of BRICS was predicated upon a common understanding and concern for sustainable and inclusive economic development, global peace and security (Netswera et al., 2017). The BRICS long-term vision and strategy endorsed in 2014 by the Heads of State at the Summit in Fortaleza, Brazil, underscored a commitment to address poverty, inequality and unemployment, which negatively impact the lives of disadvantaged, vulnerable and marginalised communities. To this end, BRICS nations have made a commitment to continuously address the following targeted issues for the restoration of social justice: i) social development; ii) education; iii) health; and iv) cultural development.

The following sections go into these various targeted areas, with the aim of understanding how BRICS countries fare in comparative terms on their social indicators. The next section delves into education, followed by social development, health, and cultural development. These have all been identified as integral to BRICS cooperation in the social sphere.

\section{SOCIAL DEVELOPMENT}

In terms of indicators for social development, proponents of the Global Multidimensional Poverty Index (MPI) suggest that development is best measured by looking at three dimensions of poverty: health (including indicators such as nutrition and child mortality), education (years of schooling and school attendance) and living standards (access to electricity, water, sanitation and assets, among others) (Netswera et al., 2017). The UNDP HDI reports and data bank provide a single 
standardised source for comparisons between the five countries. It is also important to note that many additional factors add to the daily realities of the common person that cumulatively and collectively impact on Human Dignity.

In point 32 of its declaration, the 2018 Johannesburg summit makes a point for continuous cooperation on population matters as agreed to by the respective country ministers responsible for this area. It includes issues of "women's rights, youth development and the future of work, urbanisation, migration and ageing" (Brasil, 2018), areas that among others, are at the heart of human dignity.

But the summit also emphasised the following in point 20: inclusive growth, sustainable growth and development "to provide equitable, inclusive, open, all-round innovation-driven and sustainable development, in its three dimensions economic, social and environment - in a balanced and integrated manner, towards the ultimate goal of eradicating poverty by 2030" (Brasil, 2018). The 2018 BRICS Summit highlighted the countries' commitment to the SDGs and achieving Agenda 2030's ultimate goal of eradicating poverty and inequality by 2030 through building responsive, inclusive and collective solutions to these challenges.

The Fortaleza Declaration (Brasil, 2014) adopted by the BRICS heads of state and government is a comprehensive social development plan premised on the promotion of social justice, sustainable development and improved quality of life for the citizens of member states (Netswera et al., 2017). Although the BRICS summit declarations over the last ten years including 2018 have been consistent in articulating a collective desire in this area, it is widely accepted that inequalities exist over the world in nearly all sectors, social classes and other stratifications. The BRICS are not immune to this effect of global capitalism, where Brazil and South Africa show the worst performance of the five.

Income, along with employment, is another important indicator of the quality of life. In this regard, Brazil had seen impressive per capita growth of two percentage points higher than its GDP growth rate with a significant decrease in income inequality under the previous administration (Netswera et al., 2017). However, 22 million people are now living below the poverty line and one in five families had no income under the Temer administration and the new government of Jair Bolsonaro will thus have to find ways of drawing the best lessons from the previous administrations while finding new ways of addressing persistent social challenges.

India's GDP increased by $7.7 \%$ in the fourth quarter of 2017 , bolstered by strong performance in construction, manufacturing and public services, making it the fastest-growing economy. Similarly, despite China's outstanding GDP growth performance in its latest five-year plan, 30.64 million Chinese people remain in absolute poverty. Of the BRICS nations, South Africa registered the highest unemployment rate and Gini coefficient (Netswera et al., 2017). 
The following table details the levels of inequality amongst BRICS countries. However, it also outlines figures for unemployment as a percentage of the labour force, improved levels of sanitation and improved access to drinking sources amongst the BRICS countries.

TABLE 2

BRICS levels of inequality by the Gini Coefficient (2018)

\begin{tabular}{lcccccc}
\hline $\begin{array}{l}\text { Country population } \\
\text { (HDI) (rank) }\end{array}$ & $\begin{array}{c}\text { Percentage Gini } \\
\text { Coefficient (\%) }\end{array}$ & $\begin{array}{c}\text { Unemployment } \\
\text { as a \% of } \\
\text { labour force }\end{array}$ & $\begin{array}{c}\text { Population } \\
\text { using improved } \\
\text { sanitation (\%) }\end{array}$ & $\begin{array}{c}\text { Population using } \\
\text { improved } \\
\text { drinking sources }\end{array}$ & $\begin{array}{c}\text { Overall loss } \\
\text { in HDI due to } \\
\text { inequality (\%) }\end{array}$ & $\begin{array}{c}\text { Inequality } \\
\text { adjusted HDI }\end{array}$ \\
\hline $\begin{array}{l}\text { Brazil 209.3ml } \\
\text { (0.759) (79) }\end{array}$ & 51.3 & 12.9 & 86 & 97.5 & 23 & 0.578 \\
$\begin{array}{l}\text { China 1.4bn } \\
\text { (0.752) (86) }\end{array}$ & 42.2 & 4.7 & 75 & 95.8 & 14.5 & 0.643 \\
$\begin{array}{l}\text { India 1.339bn } \\
\text { (0.640) (130) }\end{array}$ & 35.1 & 3.5 & 44.2 & 87.6 & 26.8 & 0.468 \\
$\begin{array}{l}\text { Russia 144ml } \\
\text { (0.816) (49) }\end{array}$ & 37.7 & 5.2 & 88.8 & & & \\
$\begin{array}{l}\text { South Africa 56.7ml } \\
\text { (0.699) (113) }\end{array}$ & 63.0 & 27.7 & 73.1 & 86.4 & 9.5 & 0.738 \\
\hline
\end{tabular}

Source: UNDP (2018).

The data above, highlighting the population sizes of the respective countries, illustrates that inroads have been made to address inequality by improving broad access to basic services such as sanitation, drinking water and the labour market. This element of access is proving to be too broad, especially when compared to the Gini coefficient, as the indicators do not describe the level of access or the proximity a person has to these services.

Therefore human development continues to be impacted by inequality, which remains a key challenge to be addressed amongst BRICS countries, with South Africa displaying the most prevalent levels of inequality, followed by Brazil, China, Russia, and India. In terms of unemployment rates, South Africa also leads the BRICS countries, followed by Brazil, Russia, China, and India. While making visible progress in ensuring that their populations have access to sanitation and drinking water, India remains behind other BRICS countries when it comes to accessing improved sanitation.

\section{EDUCATION}

The commitment to education displayed by BRICS nations is promising, although there is a need to accentuate the quality of educational inputs and outcomes. While the BRICS countries face common challenges, South Africa's Chairship in 2018 re-emphasised and promoted a commitment to strengthening collaboration in technical and vocational education and training (TVET); and further supporting the coordination of the BRICS Network University (BRICS, 2018). 
In measuring developments in education, internationally, the 2018 summit and ministerial meeting reaffirmed the commitment to the UN SDGs, particularly goal 4 that "ensure[s] inclusive and equitable education and promote[s] lifelong learning opportunities for all” (BRICS, 2018). The average and expected years of schooling, net enrolment ratio in primary, secondary and tertiary education, and national literacy rates of the BRICS countries depict progress towards achieving a more equitable and sustainable society.

\section{TABLE 3}

Literacy rate, adult (2018)

\begin{tabular}{lc}
\hline Country & Literacy rate, adult (\% ages 15 and older) \\
\hline Brazil & 91.7 \\
Russian Federation & 99.7 \\
India & 69.3 \\
China & 95.1 \\
South Africa & 94.4 \\
\hline
\end{tabular}

Source: UNDP (2018).

High literacy rates are associated with a high rate of individual and community progress, as well as economic development and industrialisation. The literacy rate, a percentage of the population ages 15 and older, for the BRICS is relatively high for four of the five BRICS members, with India falling below the other BRICS countries (UNDP, 2018).

Overall, in 2018 the BRICS countries average as follows in terms of expected years of schooling for males and females: Brazil (15.4), Russian Federation (15.6), India (12.4), China (15.1) and South Africa (13.4) (UNDP, 2018). All countries display data for completed primary and some secondary schooling, at minimum, which contributes to the skill set and competencies of a labour force. One particular issue facing BRICS countries is the need for quality education to reach all pupils, including rural areas.

In addition, it is important for BRICS to focus not only on access to education, but the quality of education. In addressing gender inequality in education and the expected impact on economic contributions, even though the number of years of schooling that males complete is still higher than females in some cases, the BRICS countries have shown a steady improvement over the years.

It is generally anticipated that improved access to education for women is likely to contribute to better employment and wage opportunities. However, achieving economic growth and ultimately maintaining geopolitical relevance could be hindered in highly stratified societies, where a gender imbalance already 
exists. With the creation of the BRICS Gender and Women's Forum, at the 2018 BRICS Summit, gender equality across all sectors may be promoted.

TABLE 4

Expected years of schooling (average years)

\begin{tabular}{|c|c|c|c|c|c|c|c|c|}
\hline \multirow{2}{*}{ Country } & \multicolumn{2}{|c|}{2005} & \multicolumn{2}{|c|}{2010} & \multicolumn{2}{|c|}{2015} & \multicolumn{2}{|c|}{2018} \\
\hline & Female & Male & Female & Male & Female & Male & Female & Male \\
\hline Brazil & 14.1 & 13.5 & 14.4 & 13.5 & 15.7 & 14.7 & 15.9 & 14.9 \\
\hline Russian Federation & 14.3 & 13.2 & 14.6 & 13.5 & 15.7 & 15.1 & 15.9 & 15.2 \\
\hline India & 9.1 & 10.2 & 10.5 & 11 & 12.3 & 11.6 & 12.9 & 11.9 \\
\hline China & 10.9 & 15.1 & 12.7 & 15.3 & 14.3 & 16.1 & 14 & 16.2 \\
\hline South Africa & 13.3 & 12.5 & 13.4 & 12.3 & 13.7 & 13.1 & 13.7 & 13.1 \\
\hline
\end{tabular}

Source: UNDP (2018).

The BRICS have a high gross enrolment ratio of primary and secondary schooling. A vital focus point is the gross enrolment ratio for tertiary education. Tertiary studies cover a wider spectrum of graduate and postgraduate university studies, as well as technical skills that have official certification. A higher skilled population is able to contribute to a more sophisticated labour pool in services, research and development. While the Russian Federation is highest in providing access to tertiary education, the remaining BRICS countries face additional institutional capacity challenges. The BRICS dialogue has been consistent over the years in expressing an urgent need to improve access to tertiary education for social and economic progress.

TABLE 5

Gross enrolment ratio (\% of school-age population) by primary, secondary and tertiary levels of education (2018)

\begin{tabular}{lccc}
\hline Country & $\begin{array}{c}\text { Gross enrolment ratio, } \\
\text { primary (\% of primary } \\
\text { school-age population) }\end{array}$ & $\begin{array}{c}\text { Gross enrolment ratio, } \\
\text { secondary (\% of secondary } \\
\text { school-age population) }\end{array}$ & $\begin{array}{c}\text { Gross enrolment ratio, } \\
\text { tertiary (\% of tertiary } \\
\text { school-age population) }\end{array}$ \\
\hline Brazil & 115 & 100 & 51 \\
Russian Federation & 102 & 105 & 82 \\
India & 101 & 95 & 27 \\
China & 101 & 95 & 48 \\
South Africa & 103 & 103 & 20 \\
\hline
\end{tabular}

Source: UNDP (2018).

International datasets, including the Human Development Index, need more systematic contributions in order to describe the quality of education that learners receive and their ability to contribute to a prospering socio-economic 
context, the relative or holistic support systems that foster positive learning environments and the individuals' literacy and numeracy.

In terms of statistical data presented, much of the progress in education can be characterised as 'steady' and as a result of domestic policy and focus. As there was no significant increase since the BRICS partnership came into existence (between 2010 to 2018), this is an area of cooperation that can still grow from links in the partnership.

Research undertaken by Bawa (2012) suggests that BRICS nations already play an important role in both labour supply and scientific output. However, this needs to be reflected in the quality of education that is undertaken from an early level and how it is tracked across the various levels of education, which is a more pressing issue and not reflected in the data that is often made available.

One strategy to reach high quality is Early Childhood Development (ECD). Taguma, Litjens and Makowiecki (2013) have noted that early childhood education has become a priority in many countries around the world. Similarly, there is a need for a curriculum practice in which cognitive and social development are viewed as complementary in achieving quality ECD. Of this, literacy, numeracy and information and communications technology (ICT) are among the most crucial learning areas for ECD. The MDGs underscored universal primary education stressing the need to attain universal completion of primary schooling by 2015 while the SDGs stressed the need to attain this goal by 2030 and to improve quality. While datasets portray the BRICS as on track, internationally and amongst themselves, the narratives of findings from separate in depth country studies show unique challenges that still speak to pervasive socio-economic and social justice inequalities that need to be measured more efficiently.

\section{HEALTH}

Sustaining a healthy nation and the provision of basic health services are the prerequisite for the inclusive economic development of the BRICS nations individually and collectively. The BRICS countries share a number of challenges: the burden of disease, poorly structured health systems, resource shortages and health financing, which all impact the economically vulnerable to an unprecedented level. In discussing health in the context of social justice and sustainable development, the following areas may add to a holistic picture: quality of health vis-à-vis government expenditure, life expectancy and mortality rates, and the contribution of environmentally linked health hazards.

In addressing the underlying causes to a number of key indicators (infant and maternal mortality, prevalence of disease, access to health care, average life spans, and mortality rates among men and women) it is possible to get an aggregate picture of the quality of health that is experienced by people. 
Disaggregated data on healthcare outcomes shows that an increase in healthcare expenditure, both as a proportion of GDP and as a proportion of total government expenditure, has yielded desirable results. The current health expenditure, as a percentage of the national GDP, has increased since 2005, even after the global recession occurred in 2009. This allowed more people to gain access to health care facilities and services, which is seen in stable and improving life expectancy at birth, and a reduction in the number of deaths in children under the age of five and adults. The following table shows the current health expenditure in BRICS countries as a percentage of GDP, showing a gradual increase across BRICS countries since 2005.

TABLE 6

Current health expenditure (\% of GDP)

\begin{tabular}{lcccc}
\hline Country & 2005 & 2010 & 2015 & 2018 \\
\hline Brazil & 8 & 8 & 8.9 & 8.9 \\
Russian Federation & 5.1 & 5.3 & 5.6 & 5.6 \\
India & 3.8 & 3.3 & 3.9 & 3.9 \\
China & 4.3 & 4.5 & 5.3 & 5.3 \\
South Africa & 6.7 & 7.4 & 8.2 & 8.2 \\
\hline
\end{tabular}

Source: UNDP (2018).

Life expectancy, measured in years from birth, shows the BRICS in medium to high categories of human development. In addition, women are living longer than men on average, denoting a possible improvement in the gender parity gap as more females may have better access to health care, specifically antenatal. In Brazil males live an average of 72.1 years, and females 79.3 years; in the Russian Federation males live 65.1 years and females live 76.8; in India males live 67.3 years and females live 70.4 years; in China males live 74.9 years and females live 78 years; while in South Africa males are living 59.9 years, in comparison to females living 67 years (UNDP, 2018).

\section{TABLE 7}

Life expectancy at birth (years)

\begin{tabular}{lllll}
\hline Country & 2005 & 2010 & 2015 & 2018 \\
\hline Brazil & 72 & 73.8 & 75.3 & 75.7 \\
Russian Federation & 65.8 & 68.8 & 70.9 & 71.2 \\
India & 64.6 & 66.6 & 68.3 & 68.8 \\
China & 74 & 75.2 & 76.1 & 76.4 \\
South Africa & 52.6 & 55.9 & 62 & 63.4 \\
\hline
\end{tabular}

Source: UNDP (2018).

The increase in healthcare expenditure has resulted in improved access to health care and the considerable reduction of infant and children below the age 
of 5 mortality rates across BRICS nations. For example, since 2005, India and South Africa made the most progress in reducing the number of deaths from 74.4 and 74.3 respectively, to 34.6 and 34.3 per 1,000 live births; Brazil was able to reduce this rate from 26.1 to 13.5 ; China lowered their rate from 24 to 8.5 ; and the Russian Federation lowered their rate from 13.9 to 6.6.

TABLE 8

Mortality rate, under five (per 1,000 live births)

\begin{tabular}{lllcc}
\hline Country & 2005 & 2010 & 2015 & 2018 \\
\hline Brazil & 26.1 & 19.8 & 15.7 & 13.5 \\
Russian Federation & 13.9 & 10 & 8 & 6.6 \\
India & 74.4 & 58.8 & 45.2 & 34.6 \\
China & 24 & 15.7 & 10.7 & 8.5 \\
South Africa & 74.3 & 53.7 & 44.1 & 34.2 \\
\hline
\end{tabular}

Source: UNDP (2018).

The mortality rate among adults also communicates a positive trend for health care access and improvements in the gender parity gap. Since 2005, South Africa has made the most significant progress in reducing the number of deaths from: 454 to 274 per 1,000 among females, and 563 to 396 per 1,000 among males.

TABLE 9

Mortality rate, adults - female and male (per 1,000 people)

\begin{tabular}{|c|c|c|c|c|c|c|c|c|}
\hline \multirow{2}{*}{ Country } & \multicolumn{2}{|c|}{2005} & \multicolumn{2}{|c|}{2010} & \multicolumn{2}{|c|}{2015} & \multicolumn{2}{|c|}{2018} \\
\hline & Female & Male & Female & Male & Female & Male & Female & Male \\
\hline Brazil & 111 & 225 & 102 & 208 & 95 & 194 & 94 & 191 \\
\hline Russian Federation & 173 & 465 & 137 & 366 & * & * & 120 & 322 \\
\hline India & 178 & 236 & 158 & 225 & 141 & 215 & 139 & 212 \\
\hline China & 81 & 108 & 74 & 100 & 68 & 93 & 67 & 92 \\
\hline South Africa & 454 & 563 & 389 & 510 & 289 & 414 & 274 & 396 \\
\hline
\end{tabular}

Source: UNDP (2018).

Obs.: ${ }^{*}=$ no data available.

The measurement of environment related health hazards is a relatively new trend in datasets. The BRICS have jointly agreed that closer collaboration in improving air quality and water, and attention to biodiversity, climate change and waste management are urgent. The environment not only has a direct and indirect bearing on the sustainability of economic development, but the quality of people's health.

A large amount of energy consumption is still traditionally driven, in combination with carbon dioxide emissions, the change to forest areas, 
and withdrawal from fresh water sources have a direct impact on levels of air and water pollution. Thus far, according to the UNDP HDI 2018 report, the most alarming contributor to this trend is the number of deaths related to ambient air pollution in the BRICS countries; Brazil 29.9, Russia 49.4, India 184.3, China 112.7 and South Africa 86.7. The following tables give an overview of this reality amongst BRICS countries using environmental sustainability indicators and mortality rates attributed to air and water, sanitation and hygiene pollution.

TABLE 10

Environmental sustainability indicators

\begin{tabular}{lcccc}
\hline Country & $\begin{array}{c}\text { Carbon dioxide emissions, } \\
\text { per capita (tonnes) }\end{array}$ & $\begin{array}{c}\text { Forest area, } \\
\text { change (\%) }\end{array}$ & $\begin{array}{c}\text { Fossil fuel energy } \\
\text { consumption (\% of total } \\
\text { energy consumption) }\end{array}$ & $\begin{array}{c}\text { Freshwater withdrawals } \\
\text { (\% of total renewable } \\
\text { water resources) }\end{array}$ \\
\hline Brazil & 2.6 & -9.7 & 59.1 & 0.9 \\
Russian Federation & 11.9 & 0.8 & 90.2 & 1.3 \\
India & 1.7 & 10.5 & 73.5 & 33.9 \\
China & 7.5 & 32.6 & 87.5 & 20.9 \\
South Africa & 9 & 0 & 86.9 & 30.2 \\
\hline
\end{tabular}

Source: UNDP (2018).

TABLE 11

Mortality rates attributed to air and water, sanitation and hygiene pollution (deaths per 100,000)

\begin{tabular}{lcc}
\hline Country & $\begin{array}{c}\text { Mortality rate attributed to household and ambient } \\
\text { air pollution (per 100,000 population) }\end{array}$ & $\begin{array}{c}\text { Mortality rate attributed to unsafe water, sanitation } \\
\text { and hygiene services (per 100,000 population) }\end{array}$ \\
\hline Brazil & 29.9 & 1 \\
Russian Federation & 49.4 & 0.1 \\
India & 184.3 & 18.6 \\
China & 112.7 & 0.6 \\
South Africa & 86.7 & 13.7 \\
\hline
\end{tabular}

Source: UNDP (2018).

While the measurement of environmental hazards to the quality of life and health are relatively new, the existing data allows BRICS countries and the research community to monitor progress in addressing the various environmental hazards. Apart from Brazil, BRICS countries still use relatively high levels of fossil fuels in their energy mix. However, investments into renewable energy usage will have to be monitored closely as the BRICS countries have made various commitments to grow the portion of renewables in their energy mix. While China and India have made headlines with regards deaths related to air quality, South Africa has also not fared well in comparison. India and South Africa will also have to make greater gains in reducing the mortality rates related to unsafe water, sanitation, 
and hygiene services, which are higher than their respective BRICS counterparts. This needs to be the subject of continued research and analysis.

\section{CULTURAL DEVELOPMENT}

Cultural development and exchanges are important to understanding the diversity of nations, and can stimulate innovation and development. A country's cultural development is a continuum of its way of life, which embodies value systems and practices, among other things (Netswera et al., 2017). Each country is endowed with unique cultural resources through which lessons about each society's ways of life can be learned, while debunking myths, misconceptions and misperceptions about one another as different societies. It is through these cultural exchanges that learnings about ways in which to tackle problems can be shared, while enabling BRICS nations to appreciate one another's unique historical circumstances and intersections.

The soft power potential of culture is perhaps something worth savouring for BRICS. Between ancient and contemporary Chinese, Russian, Indian, Brazilian and South African art, architecture, sounds and philosophies, the world already enjoys plenty in its varying palates. Beyond the cultural networks that accompany BRICS as a partnership, each member state is strategically and geopolitically positioned to amplify particular aspects to their region and continent.

While it is common that in former colonies, a legacy of human suffering in all its guises and causes would tend to stand firm, it may as well be easy to forget that the mixture of populations, such as those from Africa and other parts of the world, have created a rich tapestry of cultures, such as in Brazil. Dance and martial art forms, such as capoeira and others, have contributed to the attraction of Brazil as a country and society: these have fused with the various cultures of the Portuguese and Indigenous peoples of the country and region to create a melting pot of culture. Each country context is thus informed by its historical complexities.

India's cultural heritage is one of the oldest, dating back several millennia. It remains one of the most populated countries in the world. Although governed largely by the Hindu philosophy, which dictates large aspects of Indian life and cultural heritage, it also has significant varieties of communities, each with their own language, dialect and even religion. Buddhism and Islam enjoy representation in Indian history, society and state. Expressed predominantly in music, art, drama, dance and theatre, India continues to successfully export the beauty of its culture with Yoga by enjoying the International Yoga Day. These cultural commons serve as tools and celebratory forms of expression of the country's illustrious history. India's cultural heritage has influenced many countries in Southeast Asia, such as Thailand, Malaysia, Burma, and Cambodia, providing a snippet of the cultural 
make up of these surrounding societies (Netswera et al., 2017). India has a vast and rich heritage of Islamic architecture, the famous Taj Mahal being one of them. It is also home to the second largest Muslim community in the world, and its influence has played part in India's soft power development. Among BRICS nations, India has the most developed and globalised film industry, and the Indian government as well as corporations have increasingly supported and harnessed the power of Bollywood in their international interactions.

China's Great Wall for instance, tells of a story of fortitude and determination over ages; the length of time, resources spent and even lives lost for a cause as a demonstration of the lengths of human endeavour. China has also increasingly put resources towards harnessing its cultural heritage, drawing from the vast aspects of Chinese civilisation and its contemporary unprecedented story in human development, where it has uplifted approximately 800 million people from poverty since its opening and reform measures. This has been evident through the Asia civilisational dialogue platform initiated by China, which shows resources being put towards what are being termed as civilisational dialogues to tackle contemporary challenges. These would work towards building what President Xi Jinping terms a 'Community with Shared Future for Mankind'.

The role of religion in both society and the state, for instance, and the shaping of a national identity are worth exploring. An example of this point can be found in inquiries into the relations between the Russian Orthodox Church and Russian state. While one can talk of the multicultural spectrum of the Russian population and the concept of the 'Holy Rus' and religion/the church, the matter of country specific conceptualisation of modernity and civilisation must not be ignored. However, these must be seen in the context of the complexities of identity.

One among other central commonalities between countries of the South broadly is their colonial history. Particularly historical colonialism by western countries that permeates issues of infrastructure, education and academic approaches - with some in the developing world reviewing their position of what they may interpret as western modernity. An example of this can be seen in growing movements in the developing world on the decolonisation of education and areas of scholarship such as anthropology and research techniques such as ethnography.

This is increasingly being seen in South Africa twenty-five years into the country's democratic era. Among the implications of these is how the concept of democracy is viewed and applied, particularly in areas of governance and general social policy formulation. Here, both the differences and commonalities of the members of the BRICS group can serve as a collective strength in that they offer learnings.

One common expression in popular South African discourse is the idea of 'unity in diversity'. Urbanisation in South African cities like Johannesburg and 
Cape Town has allowed a mixture of cultures and identities, and has created uniqueness that has allowed for unity and the coining of the idea of a Rainbow Nation. This uniqueness has established one voice despite a number of South African official languages, in platforms like the national anthem and sports. The growth of South African music and dance that was captured in events like the 2010 FIFA World Cup continues to grow and extend collaboration to the rest of Africa and the rest of the world.

Given what is likely to be a growing role of culture as a bridge to the different BRICS countries, it will remain important to do a thorough examination of the various mechanisms being used to promote a cultural understanding of the different countries.

The BRICS have thus far showed a greater willingness and appetite to link the various people of their respective countries. This is taking place in the form of tourism, people-to-people relations, and a growing number of diplomatic tracks of engagement in the form of tracks one, two, and three that involve representation beyond government officials, but instead, broadening the engagements to think tanks and academia, and to civil society formations. These areas of cooperation will indeed build cultural bridges amongst the BRICS countries that spill over into other important areas of social development.

\section{FINAL REMARKS AND GENERAL RECOMMENDATIONS}

This paper has shown the performance of BRICS countries on various social development indicators. Indeed BRICS countries will continue to play important roles in implementing the SDGs as well as at addressing socio-economic challenges in their own countries and in other developing countries and in other developing countries.

Therefore, it is important that the BRICS nations and researchers contributing to the Academic Forum works toward recommending a mixed methodology that measures their progress over time and adapts the set of SDG targets and indicators through which progress can be assessed. Each BRICS nation should be in a position to annually report its progress through recently conducted empirical data studies, and set targets and indicators.

This paper is part of a process of developing a methodology for future use, and has outlined how the BRICS countries perform on various social development indicators. What will follow in subsequent reports and contributions to the BRICS Think Tanks Council is a proposed methodology tracking relevant indicators across the BRICS countries. This will form an important element of their contribution to implementing the SDGs. The Johannesburg 2018 summit declaration makes emphasis on the need to expand and strengthen cooperation in population matters. 
There is already cooperation by the national statistics authorities of the five countries that has produced a report on issues covering the broad scope of human development. Further developments in this area of cooperation must be monitored and evaluated timeously to assist researchers in particular, and to assist societies of the BRICS countries. The BRICS Think Tanks Council is useful in coordinating such work, especially in the realm of research and policy advice.

1) Gender parity targets: BRICS nations' development agenda should hinge on gender parity. Targets relating to a variety of development indicators like rights to economic resources, access to ownership and control over land and other forms of property, financial services and employment should address gender parity, as the empowerment of women in central to development.

2) Databases/datasets: as part of measurement tools and working towards a possible methodology, there needs to be an index of research on what has already been published, an audit of current information available, after which gaps in the research can be identified. This can form a central part of the annual reports by the BRICS Think Tanks Council, especially the chapter on Social justice, sustainable development and quality of life in the BRICS countries.

3) Poverty effects on education: Leroy and Symes (2001) see poverty as the major risk factor in education. Some of the factors that compound poverty and lead to slow progress of children in schools are: i) very young, single or low educational level parents; ii) unemployed parents; iii) abuse and neglect of children; iv) substance abuse by children; v) children living in dangerous neighbourhoods; vi) homelessness among children; vii) mobility of the family; and viii) exposure of children to inadequate or inappropriate educational experiences. BRICS nations should ensure that they jointly address these problems to enable effective educational outcomes.

4) Home-based educational support: the majority of children face problems both at school and from their families. Many parents fail to support school work for an array of reasons, which negatively affect educational outcomes. The development of curriculum strategies to improve parental participation in school work should be a priority of the BRICS nations.

5) Commitment to ensure inclusive and equitable quality education: BRICS nations should commit to ensure all girls and boys complete free, equitable and quality primary and secondary education leading to relevant and effective learning outcomes. 
6) Girl-child schooling: there are serious gender disparities in access, literacy and graduation rates, among others, with the girl-child lagging behind. BRICS nations should prioritise equal access for all girls and women to quality early childhood, primary and secondary school, technical, vocational and tertiary education, including university with monitoring.

7) Universal health insurance: the implementation of universal health insurance is inconsistent across BRICS nations. Nations have not provided specific commitments and targets achievable within a particular given period. Nations should commit to achieve universal health coverage, including financial risk protection, access to quality essential health-care services and access to safe, effective, quality and affordable essential medicines and vaccines for all.

8) Social protection: the BRICS nations should develop a medium-to long-term strategy to eradicate poverty, inequality and unemployment, aligned to the general recommendations above. This is imperative if BRICS is to meet its obligations towards the SDG targets.

9) Harnessing opportunities of urbanisation: continued urbanisation and urban growth is a clear reality despite declining rates of growth in most BRICS nations. The one exception is the Russian Federation which faces de-urbanisation or a static urban population. In all other BRICS nations, proper planning and management of rapid urbanisation is a big challenge due to unplanned housing patterns. Where urban decline is considerable, it is important to provide infrastructure, or decommission unutilised infrastructure or connecting infrastructure between cities, as well as infrastructure internal to cities, such as mobility networks. Informality in urban housing remains a big challenge for Brazil, India and South Africa, requiring the sharing of knowledge and experience amongst the BRICS countries. The BRICS should commit by 2030 to ensure access for all to adequate, safe and affordable housing; accessible and sustainable transport systems and green and public spaces in particular for women and children, older persons and persons with disabilities.

10) Culture promotion: culture and cultural exchanges leverage development and empower local communities, thereby contributing to the restoration of social justice in a sustainable way. Cultural developments and the diversity of nations need to be encouraged, nourished and shared. The interaction between indigenous culture, creative commons and other domains of society, economy and nature, enables people to come to a profound understanding of organising fields and enlarges the domain of entrepreneurial thinking and acting. BRICS nations should find mechanisms to awards grants and funds that allow and promote interactions within and between indigenous culture and creative commons. 


\section{REFERENCES}

BAWA, A. C. South African higher education: at the center of a cauldron of national imaginations. Social Research: An International Quarterly, n. 79, p. 669-694, 2012. BRASIL. Ministério das Relaçôes Exteriores. Fortaleza declaration. Fortaleza: MRE, 2014. . Ministério das Relaçóes Exteriores. Johannesburg declaration. [s.l.]: BRICS, 2018. Available at: <http://www.itamaraty.gov.br/pt-BR/notas-a-imprensa/19236-x-cupula-dosbrics-declaracao-de-joanesburgo-27-de-julho-de-2018-ingles> .

BRICS - BRASIL, RÚSSIA, ÍNDIA, CHINA E ÁFRICA DO SUL. BRICS education ministers sign deal to tackle challenges. [s.l.]: BRICS, 2018. Available at: $<$ http://www.brics2018.org.za/brics-education-ministers-sign-deal-tackle-challenges> .

LEROY, C.; SYMES, B. Teachers' perspectives on the family backgrounds of children at risk. McGill Journal of Education, v. 36, p. 45-60, 2001.

NETSWERA, G. F. et al. Social justice, sustainable development and quality of life. In: Realizing the BRICS long-term goals: road-maps and pathways - a proposal by the BRICS Think Tanks Council. [s.l.]: Ipea, 2017. p. 50-67. Available at: <http://sabtt. org.za/wp-content/uploads/2017/11/Realising-BRICS-Long-Term-Goals.pdf.>.

TAGUMA, M.; LITJENS, I.; MAKOWIECKI, K. Quality matters in early childhood education and care. Helsinki: OECD, 2013. Available at: <https://www. oecd.org/education/school/49985030.pdf.>.

UNDP - UNITED NATIONS DEVELOPMENT PROGRAMME. Human Development Index 2018. [s.l.]: UNDP, 2018. Available at: <http://hdr.undp.org/>.

\section{COMPLEMENTARY BIBLIOGRAPHY}

AMOATENG, A. Y. et al. Describing the structure and needs of families in South Africa: towards the development of a national policy framework for families. [s.l.]: CYFD/HSRC, 2004.

CALDWELL, B. J.; SPINKS, J. M. The self-transforming school. Abingdon: Routledge, 2013.

CURRY, M. S.; CADIOGAN, A. T.; GIUGLIANO, R. G. Brazil's Bolsa Familia and the Philippines' "4Ps" CCT Programs: considering South-South cooperation for social protection. Asia-Pacific Social Science Review, n. 13, p. 1-15, 2013.

DEVEREUX, S.; ROELEN, K.; ULRICHS, M. Where next for social protection? Sussex: IDS, 2015.Availableat: <http://opendocs.ids.ac.uk/opendocs/ bitstream/123456789/5945/1/ER124_WhereNextforSocialProtection.pdf>.

ENGINEERING NEWS. Housing backlog at $2.1 \mathrm{~m}$, says Minister Sisulu. Engineering News, 2016. Available at: <http://www.engineeringnews.co.za/ article/housing-backlog-at-21m-says-minister-sisulu-2016-04-22/rep_id:4136.>. 
EVOH, C. J.; MAFU, N. How 'basic' is basic education? Restructuring basic education in post-Apartheid South Africa within the context of EFA. International Perspectives on Education and Society, v. 8, p. 427-451, 2007.

FAO - FOOD AND AGRICULTURAL ORGANISATION OF THE UNITED NATIONS. The state of food insecurity in the world: meeting the 2015 international hunger targets - taking stock of uneven progress. Rome: FAO, 2015. Available at: <http://www.fao.org/3/a-i4646e.pdf>.

HOLDEN, C. Review of the global social policy in the making: the foundations of the social protection floor, by Bob Deacon. Policy Press, 2013.

ILO - INTERNATIONAL LABOUR ORGANIZATION. Social protection floor for a fair and inclusive globalization. Geneva: ILO, 2011. Available at: <http://www.ilo.org/wcmsp5/groups/public/---dgreports/---dcomm/---publ/ documents/publication/wcms_165750.pdf>.

Bolsa Família: an international example of social inclusion - an interview with Helmut Schwarzer. [s.l.]: ILO, 2015. Available at: <https://www. social-protection.org/gimi/gess/ShowWiki.action?id=3044>.

LUFFMAN, L. The importance of early childhood development. [s.l.]: [s.n.], 2013. Available at: <http://goodbye.soschildrensvillages.org.uk/news/ archive/2013/08/the-importance-of-early-childhood-development.>.

LUND, F. Changing social policy: the child support grant in South Africa. HSRC Press, 2008.

MAMI, Y. A. Early childhood education in Brazil: ECEC around the world. [s.l.]: CRN, 2013. Available at: <www.childrensearch.net/projects/ecec/2013_.>.

NASCIMENTO, P. A. Some trends in higher education and research in BRICS countries. [s.l.]: [s.n.], 2013. Available at: <www.dhet.gov.za/brics/content/ Papersforpublication/Brazil/paperpauloMeiyerNascimento2013VBricsAcedemicForum.pdf.>.

OECD - ORGANISATION FOR ECONOMIC CO-OPERATION AND DEVELOPMENT. OECD Economic Survey: South Africa 2013. [s.l.]: OECD, 2013. Available at: <http://www.dx.doi.org/10.1787/eco_surveys.zaf-2013-en>.

REISEN, H. Economic policy and social affairs in BRICS: Sustainable Governance Indicator (SGI). Gutersloh: Bertelsmann Stiftung Foundation, [s.d.]. Available at: $<$ http://www.sgi-network.org/brics/pdf/BRICS_Economy_and_Social_Affairs.pdf.>.

REPUBLIC OF SOUTH AFRICA. Education white paper 5 on early childhood education: meeting the challenge of early childhood development in South Africa. Pretoria: Government Printers, 2001. 
STATSSA - STATISTICS SOUTH AFRICA. General Households Survey 2018. Pretoria: StatsSA, 2019. Available at: <http://www.statssa.gov.za/publications/P0318/ P03182018.pdfs.

General Households Survey 2018: selected development indicators report. Pretoria: StatsSA, 2019. Available at: <http://www.statssa.gov.za/publications/ P03182/P031822018.pdf>.

TARATUKHINA, M. S. et al. Early childhood care and education in the Russian Federation. Paris: UNESCO, 2006. Available at: <http://unesdoc. unesco.org/images/0014/001491/149142e.pdf>.

TAYLOR, N. What's wrong with South African Schools? Johannesburg: JET Education Services, 2008.

TAYLOR, N.; FLEISCH, B.; SHINDLER, J. Education scenarios for 2019. Johannesburg: The Office of the Presidency, 2007.

TAYLOR, V. The institutional and developmental impact of cash grants: is South Africa transforming social policy? Cape Town: University of Cape Town, 2014.

UNESCO - ORGANIZAÇÃO DAS NAÇÓES UNIDAS PARA A EDUCAÇÃO, A CIÊNCIA E A CULTURA. BRICS building education for the future. Paris: UNESCO, 2004. Available at: <http://unesdoc.unesco.org/ images/0022/002296/229692e.pdf>.

UNPD - UNITED NATIONS POPULATION DIVISION. World urbanization prospects. New York: United Nations Department of Economic and Social Affairs, 2014.

VANDEMOORTELE, M. et al. Building blocks for equitable growth: lessons from the BRICS. [s.l.]: ODI, 2013. (Working Paper, n. 365). Available at: <www.odi.org.uk>.

WORLD BANK. World Bank Indicators. [s.l.]: World Bank, 2013. Available at: <http://data.worldbank.org/indicator>.

ZHOU, X. Early childhood education policy development in China. International Journal of Child Care and Education Policy, v. 5, p. 29-39, 2011.

ZHU, J. Early childhood education and relative policies in China. International Journal of Child Care and Education Policy, v. 3, p. 51-60, 2009. 